\title{
Joanna Kos-Łabędowicz
}

University of Economics in Katowice

e-mail: joanna.kos@ue.katowice.pl

ORCID: 0000-0002-9523-9609

\section{IS THERE AN "INTERGENERATIONAL GAP" \\ IN TRANSPORT USAGE? COMPARING TRANSPORT PREFERENCES OF SENIORS AND STUDENTS}

\author{
CZY W PREFERENCJACH TRANSPORTOWYCH \\ WYSTĘPUJE ZJAWISKO PRZEPAŚCI \\ MIĘDZYPOKOLENIOWEJ? \\ PORÓWNANIE PREFERENCJI TRANSPORTOWYCH \\ SENIORÓW I STUDENTÓW
}

DOI: $10.15611 /$ pn.2019.7.05

JEL Classification: J11, O18

Summary: The purpose of this paper is to examine the transport preferences of seniors and to identify potential differences in their use of transport compared to those of a younger generation, utilising literature analysis and subsequent descriptive and statistical analyses of data. The article outlines the problem of an ageing society and indicates factors important for the elderly when using the transport system. The results of direct research concerning the declared preferences of seniors and students in the choice of means of transport depending on the destination are presented. Seniors indicated public transport most often, but most people who could use a car preferred that choice for at least one of their destinations. For students, both car and public transport were also the two most frequently chosen means of transport. Despite the limited comparability of both groups, two issues are noteworthy - the similar proportions of preference for individual travel destinations, and the means of transport with definitely different levels of possibility of using a car. This suggests that in the case of seniors we are dealing with behaviour resulting from reasons other than transport preferences.

Keywords: transport preferences, transport behaviours, seniors, ageing society.

Streszczenie: Cele artykułu to zbadanie preferencji transportowych seniorów i wskazanie potencjalnych różnic $\mathrm{w}$ ich korzystaniu $\mathrm{z}$ środków transportu na tle młodego pokolenia. Wykorzystano następujące metody: analizę literatury, analizę opisową i statystyczną danych. W tekście zarysowano problem starzejącego się społeczeństwa oraz wskazano czynniki istotne dla osób starszych w korzystaniu z systemu transportowego. Przedstawiono wyniki badań bezpośrednich dotyczących deklarowanych preferencji seniorów i studentów w wyborze środków transportu w zależności od celu podróży. Seniorzy najczęściej wskazywali transport publiczny, niemniej większość osób mogących korzystać z samochodu deklarowała jego 
wybór do przynajmniej jednego celu podróży. W odniesieniu do studentów najczęściej jako środki transportu wybierano również samochód i transport publiczny. Mimo ograniczonej porównywalności obu grup uwagę zwracają dwie kwestie - zbliżone wartości deklaracji dotyczące poszczególnych celów podróży i środków transportu przy zdecydowanie różnych poziomach możliwości korzystania $\mathrm{z}$ samochodu. Sugeruje to, że w przypadku seniorów mamy do czynienia raczej z zachowaniami wynikającymi $\mathrm{z}$ innych uwarunkowań niż preferencje transportowe.

Slowa kluczowe: preferencje transportowe, zachowania transportowe, seniorzy, starzejące się społeczeństwo.

\section{Introduction}

The progressing ageing of society, particularly in developed countries, is increasingly attracting the attention of not only scientists and decision-makers, but also of the public, who are increasingly being exposed in everyday life to the consequences of this phenomenon. The very fact of the ageing of the population, whether in the European Union or in Poland, is not in doubt and has been the subject of many studies and reports (United Nations [UN], 2017; World Health Organization [WHO], 2018; Główny Urząd Statystyczny [GUS], 2014b). Nevertheless, in the case of some challenges related to the progressing ageing of society and requiring decisive action to meet the changing needs of elderly people, such as ensuring mobility, different housing needs, problems of forced unemployment or social exclusion (European Commission [EC], 2018), there is a lack of agreement as to the causes and scale of individual problems and the potential remedies. This is partly due to the differentiation of the age group itself, from the problems with determining their actual needs (resulting from the limited availability of this group in terms of participation and availability for the research) or the occurrence of unconscious needs. There is also the need to take into account specific factors (e.g. the place of residence, considering both rural and urban areas) or administrative and political reasons (the adopted political approach resulting from legislation and the individual approach of decisionmakers at various administrative levels). However, this topic is increasingly being raised and dealt with by Polish researchers, as exemplified by the Mig/Aging project implemented in 2013-2018 (Okólski, 2018).

The goal of this study is to examine the transport preferences of seniors and to identify potential differences in the use of individual modes of transport against those of the younger generation. In order to achieve this goal, the literature review method was used to determine the needs and preferences of seniors, and the results of the reviewed surveys on declared transport preferences of the two different age groups were presented and analysed. First and second degree students represented the young generation, and students of the Universities of the Third Age represented the seniors. The structure of the article is as follows: first, the problem of the ageing 
of the population in the European Union and in Poland is outlined, indicating current trends and important issues. Next, the issue of the needs and preferences of seniors is discussed in terms of ensuring mobility and available means of transport, especially in urban areas. The third part includes an analysis of the results of the two distinct studies mentioned earlier. The summary presents the most important conclusions and answer the question regarding the differences or similarities in the declared transport preferences between the analysed age groups.

\section{An ageing society}

The increasing ageing of society, especially in developed countries, results from many factors related to economic and social development, such as the increase in life expectancy resulting from advances in medicine and more common access to health care and lower mortality (both for infants and adults) due to the progress in the field of safety measures and prevention (Eurostat, 2019e). At the same time, decreasing birth rates and fertility rates in most developed countries accelerate the ageing process of society (Eurostat, 2019d).

The share of people aged 65 or older in the European Union in 2018 amounted to almost one-fifth (19.7\%) of the total population and was $2.6 \%$ higher than in 2008 . In Poland, the first indicator in 2018 was $17.1 \%$ (below the EU 28 average), but the growth of $3.6 \%$ from 2008 was definitely above the average (Eurostat, 2019e). Poland is not currently the fastest ageing EU country, but it is the second fastest ageing country among the ten largest in terms of population in the EU member states (Table 1).

Table 1. Indicators describing the ageing of the population for the ten most populous European Union member states as of January 1, 2019

\begin{tabular}{|l|c|c|c|c|c|}
\hline \multicolumn{1}{|c|}{ Country } & $\begin{array}{c}\text { Population } \\
\text { in millions }\end{array}$ & $\begin{array}{c}\text { Share } \\
\text { of the population } \\
\text { aged 65+ }\end{array}$ & $\begin{array}{c}\text { Change } \\
\text { between 2008 } \\
\text { and 2018 }\end{array}$ & $\begin{array}{c}\text { Share of } \\
\text { population } \\
\text { aged } 80+\end{array}$ & $\begin{array}{c}\text { Old-age } \\
\text { dependancy } \\
\text { ratio }\end{array}$ \\
\hline Germany & 83.01 & $21.4 \%$ & $1.5 \%$ & $6.2 \%$ & $32.8 \%$ \\
\hline France & 67.02 & $19.7 \%$ & $3.3 \%$ & $6.0 \%$ & $31.6 \%$ \\
\hline United Kingdom & 66.64 & $18.2 \%$ & $2.3 \%$ & $4.9 \%$ & $28.6 \%$ \\
\hline Italy & 60.35 & $22.6 \%$ & $2.4 \%$ & $7.0 \%$ & $35.2 \%$ \\
\hline Spain & 46.93 & $19.1 \%$ & $2.8 \%$ & $6.2 \%$ & $29.2 \%$ \\
\hline Poland & 37.97 & $17.1 \%$ & $3.6 \%$ & $4.3 \%$ & $25.3 \%$ \\
\hline Romania & 19.41 & $18.2 \%$ & $2.8 \%$ & $4.5 \%$ & $27.5 \%$ \\
\hline Netherlands & 17.28 & $18.9 \%$ & $4.2 \%$ & $4.5 \%$ & $29.0 \%$ \\
\hline Belgium & 11.46 & $18.7 \%$ & $1.6 \%$ & $5.6 \%$ & $29.1 \%$ \\
\hline Greece & 10.72 & $21.8 \%$ & $3.1 \%$ & $6.9 \%$ & $34.1 \%$ \\
\hline EU28 & 513.48 & $19.7 \%$ & $2.6 \%$ & $5.6 \%$ & $30.5 \%$ \\
\hline
\end{tabular}

Source: own work based on (Eurostat, 2019d, 2019e). 
Analysing data concerning the share of people aged $65+$ in the population, Poland in comparison to the EU countries selected has the lowest indicator. The situation is the same for the percentage share of $80+$ people (the lowest rate at $4.3 \%$ ) in the total population or for the old-age dependency ratio (the lowest in the group at $25.3 \%$ and considerably lower than the average value for the entire EU). Concerning the issue of the rapid increase in the share of people 65+ compared to all EU countries, Poland ranks 7 th overall. Comparing the data for the selected group, Poland ranks 2nd behind the Netherlands, which has however a much smaller population. All the countries of the so-called "The Big Four" have a higher share of both people aged $65+$ and $80+$ in the population than Poland, but with the exception of France, the increase in this share is lower (Italy and Great Britain) or much lower (Germany).

Obviously a lot depends on how this trend will look in the future - predictions regarding the share of elderly people in the population and their distribution in terms of residence in rural and urban areas are presented in Table 2.

Table 2. Polish population forecast of people aged 65 and more (in thousands and in percentage) in general and according to place of residence for 2015-2050

\begin{tabular}{|l|c|c|c|c|c|c|c|c|c|c|c|}
\hline \multirow{2}{*}{ Specification } & \multicolumn{2}{|c|}{2015} & \multicolumn{2}{c|}{2020} & \multicolumn{2}{c|}{2030} & \multicolumn{2}{|c|}{2040} & \multicolumn{2}{|c|}{2050} \\
\cline { 2 - 14 } & & thousand & $\%$ & thousand & $\%$ & thousand & $\%$ & thousand & $\%$ & thousand & $\%$ \\
\hline \multicolumn{2}{|l|}{ Total } & 38.419 & 100.0 & 38.138 & 100.0 & 37.185 & 100.0 & 35.668 & 100.0 & 33.951 & 100.0 \\
\hline $65+$ & 6.071 & 15.8 & 7.194 & 18.9 & 8.646 & 23.3 & 9.429 & 26.4 & 11.097 & 32.7 \\
\hline $80+$ & 1.560 & 4.1 & 1.684 & 4.4 & 2.206 & 5.9 & 3.373 & 9.5 & 3.537 & 10.4 \\
\hline \multirow{2}{*}{$\begin{array}{l}\text { Urban } \\
\text { areas }\end{array}$} & total & 23.129 & 100.0 & 22.716 & 100.0 & 21.618 & 100.0 & 20.234 & 100.0 & 18.826 & 100.0 \\
\cline { 2 - 13 } & $65+$ & 3.936 & 17.0 & 4.719 & 20.8 & 5.477 & 25.3 & 5.691 & 28.1 & 6.533 & 34.7 \\
\cline { 2 - 13 } & $80+$ & 966 & 4.2 & 1.076 & 4.7 & 1.482 & 6.9 & 2.207 & 10.9 & 2.143 & 11.4 \\
\hline \multirow{2}{*}{$\begin{array}{l}\text { Rural } \\
\text { areas }\end{array}$} & total & 15.290 & 100.0 & 15.421 & 100.0 & 15.567 & 100.0 & 15.434 & 100.0 & 15.125 & 100.0 \\
\cline { 2 - 12 } & $65+$ & 2.134 & 14.0 & 2.475 & 16.1 & 3.169 & 20.4 & 3.738 & 24.2 & 3.738 & 30.2 \\
\cline { 2 - 12 } & $80+$ & 594 & 3.9 & 608 & 4.0 & 723 & 4.7 & 1.165 & 7.6 & 1,165 & 9.2 \\
\hline
\end{tabular}

Source: own work based on (GUS, 2014a).

The figures presented in Table 2 are concerning in relation to the problem pointed out at EU level (Eurostat, 2019c), that in the future it should be expected that more and more elderly people will live in urban areas. This is a favourable occurrence in some respects, with cities as centres focusing on a relatively small area and social, political, economic and cultural functions may foster the greater inclusion of seniors despite the limitations resulting from their deteriorating state of health. On the other hand, one should also take into account the risks associated with higher living costs in cities, which, with limited resources at the disposal of elderly people, may affect the quality of their lives.

If the 'catching up' trend in terms of ageing persists (and current forecasts, unfortunately indicate this), we soon may become the oldest country in the European Union. Taking into account the differences in economic development, GDP per 
capita, the level of social benefits and the quality of health care between the Big Four countries (similar to the other countries of the old EU 15 included in the comparison), and Poland, one should ask whether, as a country still struggling with economic and social problems, we will be able to meet the challenges arising from the ageing of Polish society. As already mentioned, these problems relate to various aspects of life, starting with access to adequate quality medical care, to housing and transport needs and issues of the social inclusion of seniors (Ministerstwo Rodziny, Pracy i Polityki Społecznej, 2018). Considering the wide range of issues relating to the needs of an ageing society, the author decided to focus on transport needs, which will be discussed next.

\section{Transport needs and preferences of seniors}

The implementation of the rights of elderly people (resulting from various regulations at local and state level) does not always take place in a coherent and coordinated manner. This is a known problem and, unfortunately, involves many aspects described in detail by the Expert Committee on Elderly People at the Commissioner for Human Rights Office (Rzecznik Praw Obywatelskich, 2012). This study comprehensively presents various aspects related to existing and managing in an ageing society, such as participation, employment, physical culture, housing, living environment and others. However, the report does not directly consider the transport needs of elderly people. This is justified to a certain extent, as it should be remembered that transport needs (and related services) are not a need in themselves but are required to serve other purposes. For example, the employment of elderly people or their participation in social life will have an impact on shaping transport needs and appropriate planning will be important in their fulfilment, e.g. by giving greater or lesser accessibility to a given means of transport.

Seniors as participants in the transport system may assume various roles, from a passive passenger in a car (private or fee-paying) or public mass transport (public government services or private) to an active participant as a vehicle driver (car, motorbike or bicycle) or pedestrian (Kos-Łabędowicz, 2019). Attention should also be paid to the changing characteristics of the contemporary generation of seniors, especially in relation to the so-called 'young old' (age 60/65-74), i.e. the generation that is reaching or has recently reached retirement age and during occupational work and private life had the opportunity to intensively use modern information and communication solutions (ICT). This current young old age group will have different needs than any corresponding age group from the past. Popular misconceptions and stereotypes about the mobility of elderly people include convictions about their giving-up driving private cars and using other means of transport (usually public mass transport) or the smaller number of journeys made by the elderly in relation to younger people (Coughlin \& D'Ambrosio, 2012, pp. 42, 44). Another serious problem, fortunately now less frequent in research, is the tendency to treat a broadly 
defined group of seniors as a uniform entity. Transport expectations and behaviour differ according to even such basic characteristics as age. Most often in Anglo-Saxon literature, the following divisions are adopted: the aforementioned category of 'young old' (60/65-74 years), 'old old' (75-84) and 'oldest old' (85+) (Solecka, 2018). It should be noted that due to varied life expectancy, the adopted boundaries change depending on the level of social development of the country and may be lower for less developed countries (Łobodzińska, 2016). The same clear differences in transport behaviour and needs occur in a given age group due to gender ( $\mathrm{Su} \&$ Bell, 2012) or the family situation of a given individual (Hahn, Kim, Kim, \& Ulfarsson, 2016). There are definitely more differentiating factors and these may include the income of the individual or household, the network of contacts and social standing of the person or community in which they live, health condition, possession of a driving licence, place of residence and many others (Ryan, Wretstrand, \& Schmidt, 2019).

Attempts are being made to identify the general needs and expectations of seniors in terms of the transport system, mobility in urban areas and preferred means of transport. These studies are conducted usually to support the planning of activities to ensure the identification of the existing problems affecting the fulfilment of transport needs that indirectly improve the quality of life of seniors and their social inclusion (Berg, Kemperman, Kleijn, \& Borgers, 2016). Research on the national-level approach in the European Union, Norway and Switzerland has identified 11 factors that are key to promoting the mobility of older people. According to the results of that research a senior-friendly transport system should be: affordable, available, barrier-free, comfortable, comprehensible, efficient, friendly, reliable, safe, secure and transparent (Johnson, Shaw, Berding, Gather, \& Rebstock, 2017). From the point of view of ensuring the mobility of elderly people in urban areas, it is important to pay attention, not only to the transport system itself, but also to the urban planning, which will affect the availability and accessibility of different means of transport (Żakowska, 2014). Access to a means of transport, both in terms of physical access (e.g. distance to a public transport stop), affordability (in relation to the income at the senior's disposal), state of the infrastructure (footpaths, pedestrian crossings, stops etc) and quality of transport (perceived safety, cleanliness, comfort) will also influence the seniors' choice of means of transport (Rahman, Strawderman, AdamsPrice, \& Turner, 2016; Wong, Szeto, Yang, Li, \& Wong, 2018).

In the literature on the subject, a lot of attention is paid to the modal choices of the individuals and their changes through their life course (Beige \& Axhausen, 2017). There is ongoing discussion to what extent age can be considered as a significant determination of the modal choice (De Witte, Hollevoet, Dobruszkes, Hubert, \& Macharis, 2013). Mobility biographs with correlation to important life events (like childbirth, residential relocation and changes in employment or educational status) that serve as mobility milestones and potentially can be used to explain changes in travel patterns and behaviour (Rau \& Manton, 2016; Clark, 
Chatterjee, \& Melia, 2016) are more often being used. As the analysis of the factors indicated as important in the literature from the point of view of meeting the transport needs of older people, it can be seen that, apart from a group of unique factors related mainly to their state of health, a large proportion of them are also important for other age groups. This observation with the earlier stated reservation about the potential relevance of the age will now be considered for the two age groups being compared in relation to transport preferences. Those two age groups include young adults (students) and seniors as the border groups on the life cycle - one entering their independent adulthood (going through the change in educational status and potentially residential relocation) and one leaving the workforce (thus bypassing another potentially important mobility milestone).

\section{Declared transport preferences of seniors and students}

In this part of the paper, the results of two direct research studies concerning the declared preferences regarding the most frequently used means of transport, depending on the purpose of travel, will be presented. The first of the discussed studies concerned the impact of the development of information and communication technologies (ICT) on meeting the transport needs of active seniors and was conducted using an auditory survey in Dec 2018 and Jan 2019 on a sample of 400 students from seven Universities of the Third Age (U3A) from five cities of the Silesian region (Bieruń, Dąbrowa Górnicza, Katowice, Rybnik, Sosnowiec). The respondents were asked to answer a number of questions about their transport preferences (choice of means of transport, degree of satisfaction), use of modern technologies (Internet, mobile phone) and use of a number of information and communication solutions (ICT) used in transport services (e.g. mobile applications, mobile timetables, purchase of tickets online) and their assessment in terms of their usefulness and ease of use, etc. The questionnaire also contained questions about the different characteristics of the respondents, like age, having a driving licence etc. Since the majority of U3A courses allowed the enrolment of people aged 50+, 22 respondents did not meet the adopted criteria defining seniors and five people did not specify their age, so their answers were not taken into account in the analysis. For the purposes of this study, the results regarding the answers to the most frequently used means of transport depending on the destination are presented (Table 3 ).

The respondents had a choice of six means of transport: car, public transport, motorcycle, taxi, bicycle and by foot. In the case of a car a distinction was made whether a person travelled as a driver or was a passenger. It was possible to choose the option 'not applicable' if the given respondent does not make this type of travel for some reason (e.g. a third party, guardian or family is shopping for them). The table shows the percentage shares of the declared use of individual means of transport (the highest values are shown in bold). Due to the lack of indication of the motorcycle as the preferred means of transport for any of the destinations, it was omitted from Table 3. 
Table 3. Declared share (\%) of preferred means of transport depending on the destination - seniors

\begin{tabular}{|l|r|r|r|r|r|r|r|r|}
\hline $\begin{array}{c}\text { Mode of } \\
\text { transportation }\end{array}$ & $\begin{array}{c}\text { Car (as } \\
\text { driver) }\end{array}$ & $\begin{array}{c}\text { Car (as } \\
\text { passenger) }\end{array}$ & $\begin{array}{c}\text { Car } \\
\text { (total) }\end{array}$ & $\begin{array}{c}\text { Public } \\
\text { transport }\end{array}$ & Taxi & Bicycle & Walk & N.A.* \\
\hline Work/School & $8.85 \%$ & $2.68 \%$ & $11.53 \%$ & $22.79 \%$ & $0.0 \%$ & $0.80 \%$ & $7.24 \%$ & $\mathbf{5 7 . 6 4 \%}$ \\
\hline Shopping & $22.25 \%$ & $11.53 \%$ & $\mathbf{3 3 . 7 8 \%}$ & $25.47 \%$ & $0.0 \%$ & $1.34 \%$ & $24.66 \%$ & $14.75 \%$ \\
\hline Personal affairs & $22.79 \%$ & $8.85 \%$ & $31.64 \%$ & $\mathbf{3 6 . 1 9 \%}$ & $0.54 \%$ & $1.34 \%$ & $15.82 \%$ & $14.48 \%$ \\
\hline Social gatherings & $16.35 \%$ & $13.94 \%$ & $30.29 \%$ & $\mathbf{3 8 . 3 4 \%}$ & $4.49 \%$ & $1.07 \%$ & $13.40 \%$ & $12.60 \%$ \\
\hline Recreation/Sports & $14.48 \%$ & $6.70 \%$ & $21.18 \%$ & $19.03 \%$ & $0.0 \%$ & $9.12 \%$ & $\mathbf{3 1 . 1 0 \%}$ & $19.57 \%$ \\
\hline $\begin{array}{l}\text { Culture/ } \\
\text { Entertainment }\end{array}$ & $16.62 \%$ & $11.26 \%$ & $27.88 \%$ & $\mathbf{4 5 . 0 5 \%}$ & $1.61 \%$ & $0.80 \%$ & $7.51 \%$ & $17.16 \%$ \\
\hline $\begin{array}{l}\text { Care for a family } \\
\text { member }\end{array}$ & $16.62 \%$ & $8.85 \%$ & $25.47 \%$ & $14.75 \%$ & $1.07 \%$ & $0.27 \%$ & $5.90 \%$ & $\mathbf{5 2 . 5 5 \%}$ \\
\hline
\end{tabular}

*Not applicable.

Source: own study based on direct research.

Public transport is actually indicated as the most frequently used means of transport in relation to as many as four of the indicated travel destinations: shopping, personal affairs, social gatherings and entertainment. If the figures for the "not applicable' answer are not taken into consideration, public transport would also be the most frequently chosen means of transport for commuting to work/school. Only in the case of recreation/sports and caring for a family member were other means of transport more often indicated - walking and driving (as a driver), respectively. Such a large share of public transport would seem to confirm the stereotype mentioned earlier about older people giving up the car in favour of this type of transport. However, a closer look at individual values suggests a slightly different situation. In the case of the shopping destination, the differences in the figures between the three most popular declared means of transport, i.e. $25.47 \%$ for public transport, $24.66 \%$ for pedestrian transport and $22.25 \%$ for the car (with the respondent as a driver), are relatively small. If, additionally, the role played by the respondent when traveling by car is included, the figure for the car as a means of transport will be $33.78 \%$ and will significantly exceed the figure for using public transport. For such travel purposes as personal affairs or social gatherings, the car will still remain in second place compared to public transport, but the difference will be $4.56 \%$ and $8.04 \%$, respectively. The only destination for which the advantage of public transport over the car is beyond doubt is entertainment/culture, $45.05 \%$ compared to $27.88 \%$ respectively. Considering that nearly 142 respondents declared having no driving licence and 215 not having a car, the assumption for giving up the use of the car seems unjustified. This is further confirmed by the fact that of those declaring having a car and a driving licence, as many as 82 indicated the car (with the respondent as the driver) as the preferred means of transport for at least three of the possible destinations. 
Naturally the presented results cannot be used to infer anything about elderly people in general - it should be remembered that U3A students should be perceived as active seniors, i.e. those who actively participate in social life and are not as much at the risk of exclusion (social or digital) as most of this age group. The second major limitation is the over-representation of women in the study group - they constituted as much as $84.99 \%$ of respondents.

The second of the discussed studies concerned the development potential of car sharing and carpooling systems in Poland and was carried out in the spring of 2016 using the CAWI (Computer Aided Web Interviewing) method among 1st and 2nd degree students of universities in nine Polish cities (Katowice, Kielce, Kraków, Lublin, Opole, Poznań, Warsaw, Wrocław and Szczecin). The respondents were asked to answer a number of questions regarding their transport preferences (choice of means of transport, degree of satisfaction), issues related to car ownership (disadvantages, advantages) as well as awareness and use of mobility-sharing solutions (carpooling and carsharing systems). This survey also contained classification questions. In total, 452 questionnaires were subjected to analysis after rejecting incomplete or incorrectly completed forms. Compared to the cited study on seniors, the sample was more representative according to the general population of Polish students (Kos-Łabędowicz \& Urbanek, 2017). Answers regarding the most frequently chosen means of transport in relation to particular destinations are presented in Table 4.

Table 4. Declared share (\%) of preferred means of transport depending on the destination - students

\begin{tabular}{|l|c|c|c|c|c|c|c|}
\hline $\begin{array}{c}\text { Mode of } \\
\text { transportation }\end{array}$ & $\begin{array}{c}\text { Car } \\
\text { Destination }\end{array}$ & $\begin{array}{c}\text { Car (with } \\
\text { other } \\
\text { alone) }\end{array}$ & $\begin{array}{c}\text { Car } \\
\text { people) }\end{array}$ & $\begin{array}{c}\text { Public } \\
\text { (total) }\end{array}$ & Taxi & Bicycle & Walk \\
\hline School / Work & $18.8 \%$ & $8.0 \%$ & $26.8 \%$ & $\mathbf{5 1 . 3 \%}$ & $0.0 \%$ & $1.8 \%$ & $20.1 \%$ \\
\hline Shopping & $19.5 \%$ & $21.2 \%$ & $\mathbf{4 0 . 7 \%}$ & $18.1 \%$ & $0.0 \%$ & $4.4 \%$ & $36.7 \%$ \\
\hline Personal affairs & $35.8 \%$ & $8.4 \%$ & $\mathbf{4 4 . 2 \%}$ & $33.6 \%$ & $0.4 \%$ & $2.9 \%$ & $18.8 \%$ \\
\hline Social gatherings & $11.5 \%$ & $15.0 \%$ & $26.5 \%$ & $\mathbf{4 3 . 8 \%}$ & $4.0 \%$ & $2.4 \%$ & $23.2 \%$ \\
\hline Recreation & $9.5 \%$ & $164 \%$ & $25.9 \%$ & $17.9 \%$ & $0.7 \%$ & $26.5 \%$ & $\mathbf{2 9 . 0 \%}$ \\
\hline
\end{tabular}

Source: based on (Kos-Łabędowicz \& Urbanek, 2017, p. 412).

In this case the respondents had a choice of five means of transport (in the case of a car, the number of travellers in a car was noted due to the purpose of the study, i.e. the potential for sharing a means of transport) and five destinations. The results obtained among students indicate the greatest popularity of public transport in the case of commuting to school/work and social gatherings, the car in the case of shopping and personal affairs and by foot for recreation. The fact that in this group as many as $82.1 \%$ of respondents declared having a driving licence and $33.8 \%$ and $32.7 \%$ had access to one or two cars that they can use (in total two-thirds of students had access to a car) is worth noting (Kos-Łabędowicz \& Urbanek, 2017). 
An important restriction to attempts to interpret and compare the presented data are the limitations of both referenced studies, which were described in each case. Due to that any conclusions can serve at most as a basis for conducting further studies that will be specifically dedicated to the preferences regarding the choice of means of transport for elderly people and the factors affecting it. However, it is impossible not to notice the similarity in the declared preferences regarding the indicated means of transport - in both groups the car was most often indicated as the means for shopping, public transport for socialising and walking for recreation. At the same time, attention should be paid to the disproportions regarding possession of a driving licence in both groups of about $60 \%$ and over $80 \%$, or access to a car - about $40 \%$ and over $60 \%$. The quoted values should not be compared directly, due to previously indicated reservations about research methods, differences in the design of the research methods and the representativeness of both samples. Nevertheless the question arises whether age is the main reason for the observed differences. The observed differences can suggest a new research direction, to determine if problems related to competences (lack or possession of a driving licence) or material situation (access or not to a car) are responsible. This changes the sense of the question from differences in the needs between generations to differences in other determinants for both age groups.

\section{Conclusion}

In summary, the paper outlines the problem of an ageing society, both in the European Union and in Poland based on available statistical data and the reports of international organisations. In the case of Poland, attention was drawn to the current situation and forecasts according to which the ageing process of Polish society will progress and increasingly affect urbanized areas. Next, attention was drawn to the needs of seniors, especially in the field of transport and mobility, which are important for ensuring the adequate quality of life and social inclusion. Existing stereotypes regarding the mobility of elderly people were pointed out. The transport needs of the elderly were also discussed and a number of factors influencing the use of the transport system or promoting mobility in urban areas were highlighted. These factors are important especially in relation to the diversity of preferences of older people within the group and because of other economic or social conditions.

Theoretical considerations carried out on the basis of a literature analysis in the area of transport and mobility were followed by a presentation and analysis of the direct research results regarding the declared preferences in the choice of the means of transport by students and seniors depending on the purpose of travel. The results regarding the declared preferences were described, taking into account various means of transport (e.g. car, public transport, bicycle) and various travel destinations (e.g. shopping, social gatherings, entertainment). Limitations were indicated for both 
studies, noting the differences in the methods, tools and characteristics of both study samples, preventing a direct comparison of the two groups, and only allowing careful observation of the differences and similarities.

The attractiveness of the car as the preferred means of transport has been confirmed (Raczyńska-Buława, 2017). Consistently with the results obtained, most elderly people who can use a car (having a driving licence and having access to a vehicle) declared the choice of this means of transport for at least one of the destinations, and 82 people (over 20\%) in the case of at least three (of seven) possible destinations. Public transport is undoubtedly an important means of transportation for seniors, but not for all travel destinations (e.g. recreation/sport) and its prevalence is not always clear (except for the purpose of culture/entertainment). It would be reasonable to ask the question whether choosing public transport is a preference or a necessity due to the lack of other available options.

In the case of research concerning both students and seniors, the surveys showed that the two most frequently chosen means of transport are the car and public transport. Obviously the preferences declared by both groups cannot be directly compared (due to the indicated differences in the case of both studies), but two issues are noteworthy - the similar declared indications for individual travel destinations and means of transport at definitely different levels of the possibility of using a car (whether in terms of competence or access to a vehicle). At this point, instead of inferring the existence of an intergenerational difference (or gap) in transport preferences, it seems more reasonable to reformulate the research question and direct attention to other conditions affecting the declared preferences and actual transport behaviour of seniors.

\section{Bibliography}

Beige, S., \& Axhausen, K. W. (2017). The dynamics of commuting over the life course: Swiss experiences. Transportation Research Part A, 104, 179-194. DOI: 10.1016/j.tra.2017.01.015

Berg, P., Kemperman, A., Kleijn, B., \& Borgers, A. (2016). Ageing and loneliness: The role of mobility and the built environment. Travel Behaviour and Society, 5, 48-55. Accessed: 10.1016/j.tbs.2015.03.001

Clark, B., Chatterjee, K., \& Melia, S. (2016). Changes to commute mode: The role of life events, spatial context and environmental attitude. Transportation Research Part A, 89, 89-105. DOI: 10.1016/j. tra.2016.05.005

Coughlin, J. F., \& D’Ambrosio, L. (Eds.). (2012). Aging America and transportation. New York: Springer Publishing Company.

De Witte, A., Hollevoet, J., Dobruszkes, F., Hubert, M., \& Macharis, C. (2013). Linking modal choice to motility: A comprehensive review. Transportation Research Part A, 49, 329-341. DOI: 10.1016/j. tra.2013.01.009

European Commission [EC]. (2018). The 2018 ageing report. Underlying assumptions\& projection methodologies. ISSN 2443-8014. Retrieved from https://ec.europa.eu/info/sites/info/files/ economy-finance/ip065_en.pdf 
Eurostat. (2019a). Fertility statistics. Retrieved from https://ec.europa.eu/eurostat/statistics-explained/ index.php?title=Fertility_statistics

Eurostat. (2019b). Mortality and life expectancy statistics. Retrieved from https://ec.europa.eu/eurostat/ statistics-explained/index.php?title=Mortality_and_life_expectancy_statistics

Eurostat. (2019c). People in the EU - statistics on an ageing society. Retrieved from https://ec.europa. eu/eurostat/statistics-explained/index.php?title=People_in_the_EU_-_statistics_on_an_ageing_ society\#Elderly_population_structure_and_dependency_rates

Eurostat. (2019d). Population on 1 January. Retrieved from https://ec.europa.eu/eurostat/tgm/table.do $?$ tab $=$ table \&plugin $=1 \&$ language $=$ en $\&$ pcode $=$ tps 00001

Eurostat. (2019e). Population structure and ageing. Retrieved from https://ec.europa.eu/eurostat/ statistics-explained/index.php?title=Population_structure_and_ageing\#The_share_of_elderly_ people_continues_to_increase

Główny Urząd Statystyczny [GUS]. (2014a). Prognoza ludności na lata 2014-2050 - aneks. Retrieved from http://stat.gov.pl/obszary-tematyczne/ludnosc/prognoza-ludnosci/prognoza-ludnosci-nalata-2014-2050-opracowana-2014-r-, 1,5.html

Główny Urząd Statystyczny [GUS]. (2014b). Sytuacja demograficzna osób starszych i konsekwencje starzenia się ludności Polski w świetle prognozy na lata 2014-2050. Retrieved from https://stat. gov.pl/obszary-tematyczne/ludnosc/ludnosc/sytuacja-demograficzna-osob-starszych-ikonsekwencje-starzenia-sie-ludnosci-polski-w-swietle-prognozy-na-lata-2014-2050,18,1.html

Hahn, J.-S., Kim, H.-Ch., Kim, J.-K., \& Ulfarsson, G. (2016). Trip making of older adults in Seoul: Differences in effects of personal and household characteristics by age group and trip purpose. Journal of Transport Geography, 57, 55-62. DOI: 10.1016/j.jtrangeo.2016.09.010

Johnson, R., Shaw, J., Berding, J., Gather, M., \& Rebstock, M. (2017). European national government approaches to older people's transport system needs. Transport Policy, 59, 17-27. DOI: 10.1016/j. tranpol.2017.06.005

Kos-Łabędowicz, J. (2019). ICT in meeting the transport needs of seniors: An opportunity or a threat? Information Systems in Management, 8(1), 26-36. DOI: 10.22630/ISIM.2019.8.1.3

Kos-Łabędowicz, J., \& Urbanek, A. (2017). The potential for the development of carsharing and carpooling systems: A survey-based analysis of university students in Poland. International Journal of Transport Economics, XLIV(3), 399-425. DOI: 10.19272/201706703003

Łobodzińska, A. (2016). Starzejące się społeczeństwo wyzwaniem dla zrównoważonego rozwoju. Prace Geograficzne, 144, 127-142. DOI: 10.4467/20833113PG.16.007.5132

Ministerstwo Rodziny, Pracy i Polityki Społecznej. (2018). Informacja o sytuacji osób starszych w Polsce za rok 2017. Retrieved from https://www.gov.pl/web/rodzina/informacja-o-sytuacjiosob-starszych-za-rok-2017

Okólski, M. (Ed.). (2018). Wyzwania starzejącego się społeczeństwa. Polska dziś i jutro. Warszawa: Wydawnictwo Uniwersytetu Warszawskiego.

Raczyńska-Buława, E. (2017). Mobilność osób starszych. Dlaczego nie transport publiczny? TTS Technika Transportu Szynowego, 1-2, 24-34.

Rahman, M., Strawderman, L., Adams-Price, C., \& Turner, J. (2016). Transportation alternative preferences of the aging population. Travel Behaviour and Society, 4, 22-28. DOI: 10.1016/j.tbs.2015.12.003

Rau, H., \& Manton, R. (2016). Life events and mobility milestones: Advances in mobility biography theory and research. Journal of Transport Geography, 52, 51-60. DOI: 10.1016/j.jtrangeo.2016.02.010

Ryan, J., Wretstrand, A., \& Schmidt, S. (2019). Disparities in mobility among older people: Findings from a capability-based travel survey. Transport Policy, (79), 177-192. DOI: 10.1016/j.tranpol.2019.04.016

Rzecznik Praw Obywatelskich. (2012). Strategie działania w starzejacym się społeczeństwie. Tezy i rekomendacje. Retrieved from https://www.rpo.gov.pl/pliki/13541772380.pdf

Solecka, K. (2018). Potrzeby osób starszych w zakresie mobilności w mieście. Autobusy, (6), 12521259. DOI: $10.24136 /$ atest.2018.262 
Su, F., \& Bell, M. (2012). Travel differences by gender for older people in London. Research in Transportation Economics, 34, 35-38. DOI: 10.1016/j.retrec.2011.12.011

United Nations [UN]. (2017). World population ageing. Highlights. Retrieved from: https://www.un. org/en/development/desa/population/publications/pdf/ageing/WPA2017_Highlights.pdf

Wong, R. C. P., Szeto, W. Y., Yang, L., Li, Y. C., \& Wong, S. C. (2018). Public transport policy measures for improving elderly mobility. Transport Policy, 63, 73-79. DOI: 10.1016/j.tranpol.2017.12.015

World Health Organization [WHO]. (2018). The global network for age-friendly cities and communities: Looking back over the last decade, looking forward to the next. Retrieved from: https://www.who. int/ageing/publications/gnafcc-report-2018/en/

Żakowska, M. (Eds.). (2014). Miasta przyjazne starzeniu: Przewodnik. Retrieved from: http://publica. $\mathrm{pl} /$ produkt/miasta-przyjazne-starzeniu-przewodnik-2 